\title{
The Persistent and Exceptional Intensity of American Religion: A Response to Recent Research
}

\author{
Landon Schnabel, ${ }^{a}$ Sean Bock ${ }^{b}$
}

\author{
a) Indiana University Bloomington; b) Harvard University
}

\begin{abstract}
Recent research argues that the United States is secularizing, that this religious change is consistent with the secularization thesis, and that American religion is not exceptional. But we show that rather than religion fading into irrelevance as the secularization thesis would suggest, intense religion-strong affiliation, very frequent practice, literalism, and evangelicalism-is persistent and, in fact, only moderate religion is on the decline in the United States. We also show that in comparable countries, intense religion is on the decline or already at very low levels. Therefore, the intensity of American religion is actually becoming more exceptional over time. We conclude that intense religion in the United States is persistent and exceptional in ways that do not fit the secularization thesis.
\end{abstract}

Keywords: religion; secularization; social change

Citation: Schnabel, Landon, and Sean Bock. 2017. "The Persistent and Exceptional Intensity of American Religion: A Response to Recent Research." Sociological Science 4: 686-700.

Received: October 19, 2017

Accepted: October 31, 2017

Published: November 27, 2017

Editor(s): Jesper Sørensen, Olav Sorenson

DOI: $10.15195 / \mathrm{v} 4 . \mathrm{a} 28$

Copyright: (C) 2017 The Author(s). This open-access article has been published under a Creative Commons Attribution License, which allows unrestricted use, distribution and reproduction, in any form, as long as the original author and source have been credited. (0)(1)
MERICANS have rapidly disaffiliated from religion since the late 1980s (Hout and Fischer 2014). Some argue the religious change occurring in the United States is consistent with the secularization thesis (e.g., Bruce 2011; Marwell and Demerath 2003), but others disagree (e.g., Hout and Fischer 2002, 2003, 2014). The secularization thesis asserts that as a result of ongoing modernization and the advance of science, religion will become increasingly irrelevant in public and private life. This pattern appears to be borne out in several advanced industrial societies where religion has grown increasingly irrelevant in the public sphere and in people's everyday lives, but whether the United States fits this pattern is less clear. Voas and Chaves (2016) recently challenged the notion that American religion is exceptional and provided a persuasive argument that the United States fits the secularization thesis. Demonstrating a clear downward trend in American religiosity as measured by affiliation, practice, and belief, ${ }^{1}$ they concluded the United States is secularizing in the same way as comparable countries. We are convinced by the steep downward trend in average religiousness noted by Voas and Chaves (2016). Clearly, America appears to be secularizing. We are not yet convinced, however, by the assertion that the religious change occurring in the United States fits the secularization thesis. Is America really secularizing like other countries where religion is simply fading into obscurity? Or could average U.S. religiosity be declining despite, or maybe even because of, persistently intense religion?

Most research on religious change in the United States has focused on the rise of the unaffiliated or on declining average religiosity. Therefore, we know less about whether and how intense religion ${ }^{2}$ (e.g., strong affiliation, very frequent religious practice, biblical literalism, and evangelicalism) — arguably the most socially impactful type of religion-is changing. If the United States fits the secularization 
thesis, then we might expect that the most intensely religious Americans are moving toward being moderately religious and the moderately religious toward leaving religion altogether. Rather than symmetric decline across all levels of religiosity, however, religious change in the United States could be driven by a decline of moderate religion. The downward trend in average American religiousness may then be less the result of a society-wide fading of the importance of religion to people's lives - which we would expect on the basis of the secularization thesis-and more a function of the politicization of American religion in the late 1980s following the rise of the Christian Right. This politicization of American religion may have, as Hout and Fischer $(2002,2014)$ suggested, driven moderates out of religion but not necessarily decreased the intensity of American religion.

In fact, moderates leaving religion in America could be, at least in part, a reaction against high-intensity American religionists, strict religion, and the contemporary link between religion and right-wing politics in the United States (Djupe, Neiheisel, and Sokhey 2017; Hout and Fischer 2002, 2014). As Iannaccone (1994) contended, strict religion with intense requirements and sectarian worldviews is particularly strong in the United States. In addition to stating that a moderate level of strictness strengthens commitment to religion, Iannaccone also argued that too much strictness and intensity can push away those more loosely tied to religion. If it is primarily moderate religionists and those with loose ties to their religions driving the decline in average American religiosity, then we may be seeing more of a polarization of religion than a pattern consistent with the secularization thesis. American religion, therefore, may be persistently relevant to the public sphere, and intense religionists may increasingly define religious perspectives. Cultural divides could subsequently become even more pronounced, as there are fewer moderately religious people to bridge the divide between intense religionists and secularists.

Although religion in America may be following the trend of other countries on average, on the basis of Hout and Fischer's $(2002,2014)$ work on the politicization of American religion, we suspect that intense religionists will increasingly define religion in the United States and that this religious makeup is-and will continue to be-unique compared to other wealthy, secularizing countries. Using data from the General Social Survey (1989 to 2016) - the same data used by Voas and Chaves as well as Hout and Fischer-and the International Social Survey Programme (ISSP) (1991, 2008, and 2014), we show that the United States has demonstrated sustained levels of intense religiosity across key measures over the past few decades that are unique when compared to other advanced industrial societies. We argue, therefore, that religious change in the United States is demonstrably different than that occurring in comparable countries and that the United States remains an exceptional outlier and potential counterexample to the secularization thesis.

\section{The Persistent Intensity of American Religion}

Using the General Social Survey, we disaggregate the highest and lowest religion categories from the middle categories to examine change (or lack thereof) in the percentage of people across three groups: the most intensely religious, the least religious, and those in between. Our figures will present the percentage of Americans 


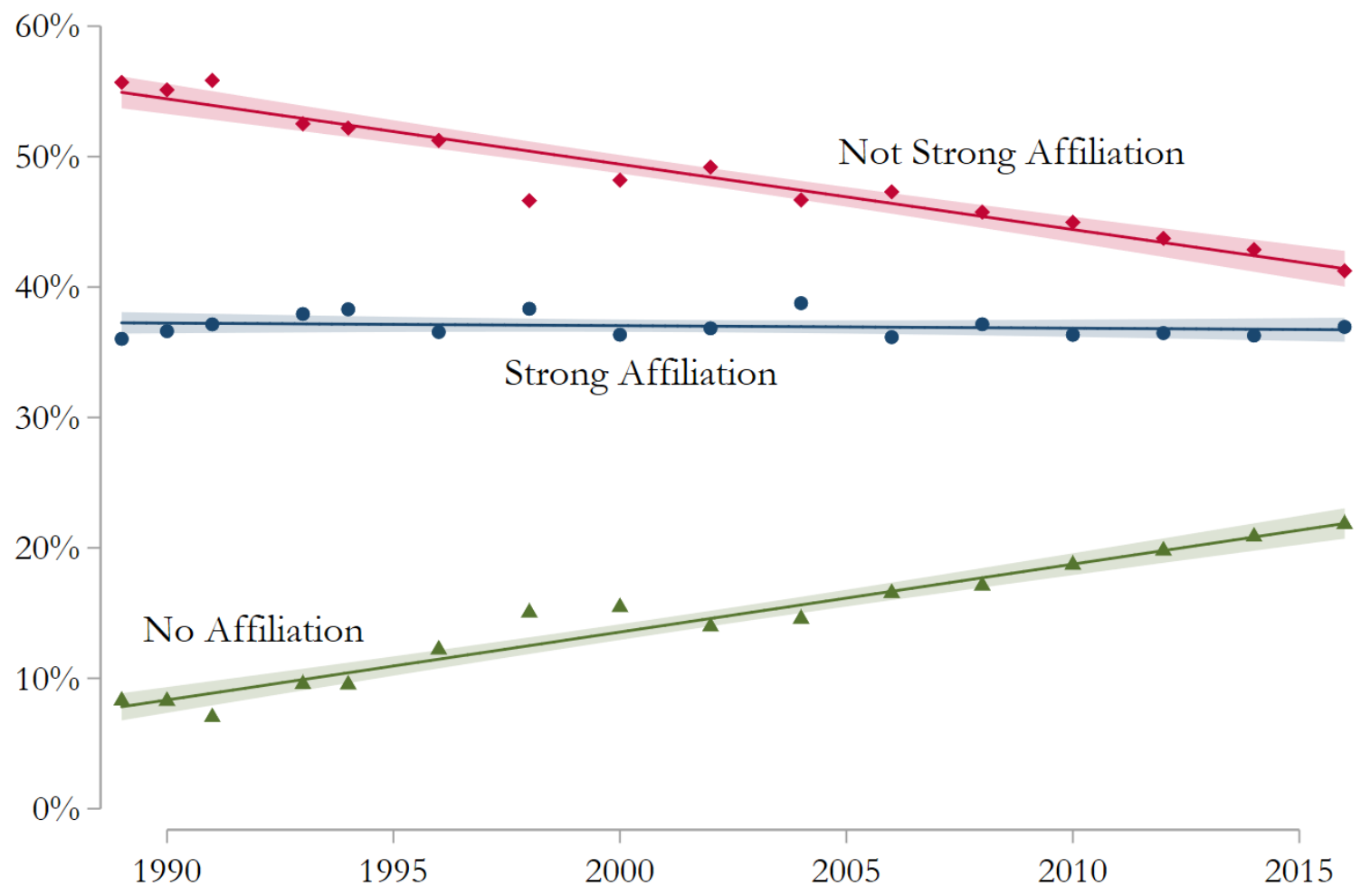

Figure 1: Strength of affiliation over time, General Social Survey. Source: General Social Survey, 1989 to 2016. Note: The GSS affiliation strength categories are created by using two items. First, respondents are asked their affiliation. If they have one, they are then asked whether they are a strong or not strong [their affiliation]. "Not strong" affiliation in the figure includes both those who said they had a "not strong" affiliation and those who volunteered "somewhat strong."

in each of these categories over time-in addition to accompanying trend lines ${ }^{3}$ and 95 percent confidence intervals-for measures of belonging, behaving, and believing that measure both levels of religiousness (strength of affiliation, prayer frequency, and attendance frequency) and types of religious belief and identity (view of the Bible and type of affiliation). By focusing on the highest categories-such as being "strongly" affiliated, attending religious services more than once a week, and believing in biblical literalism-we parallel Iannaccone's (1994) work on strict religion. We focus on the time period from the end of the 1980s to today, during which disaffiliation has been occurring most rapidly, but we will also note some longer-term patterns for measures available back to the 1970s. ${ }^{4}$

Looking first at strength of religious affiliation over time in Figure 1, we see the known pattern of the rapid rise of the unaffiliated, who have more than doubled as a percentage of the total population from 1989 to 2016. But we also find a patently persistent level of strong affiliation from 1989 to 2016. There is some year-to-year fluctuation but a very stable trend line. ${ }^{5}$ Therefore, as Figure 1 clearly demonstrates, 


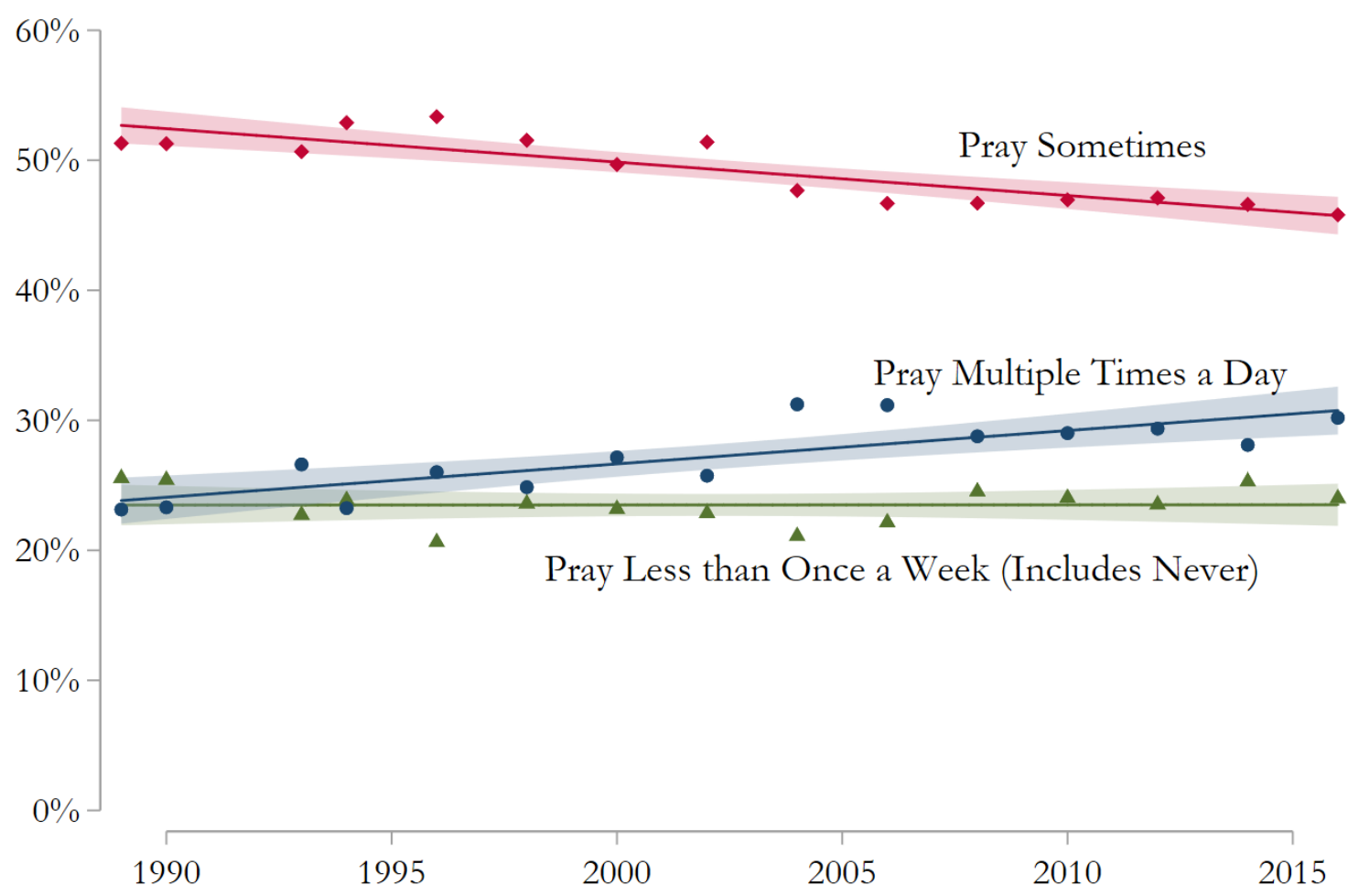

Figure 2: Prayer frequency over time, General Social Survey. Source: General Social Survey, 1989 to 2016. Note: The five consistent GSS prayer response options are less than once a week $=1$, once a week $=2$, several times a week $=3$, once a day $=4$, and several times a day $=5$. Before 2004 the GSS question did not include a "never" option, though a few people did volunteer it, and praying less than once a week was the most infrequent response option stated in the survey. After 2004, the GSS included "never" as an option. We combine less than once a week and never to make the values comparable over time. "Pray sometimes" includes options 2 through 4 .

the rise of the unaffiliated is due solely to a dramatic decline of the moderately religious. Because strong affiliation remains stable while weaker affiliations have declined, those with a strong affiliation actually make up a larger share of the affiliated population over time. In 1989, 39 percent of those with an affiliation were strongly affiliated (36 percent of Americans had a strong affiliation, which is 39 percent of the 92 percent of Americans who were religiously affiliated in 1989). But in 2017, 47 percent of those with an affiliation were strongly affiliated. Therefore, as a larger proportion of the population disaffiliates, a larger share of the remaining religionists identify as more intensely religious. ${ }^{6}$ Additional analyses demonstrate that the growing proportion of intense religionists-as measured by strength of affiliation and other religion indicators-remains important for predicting politics. In fact, as might be expected on the basis of Hout and Fischer's work on politics 


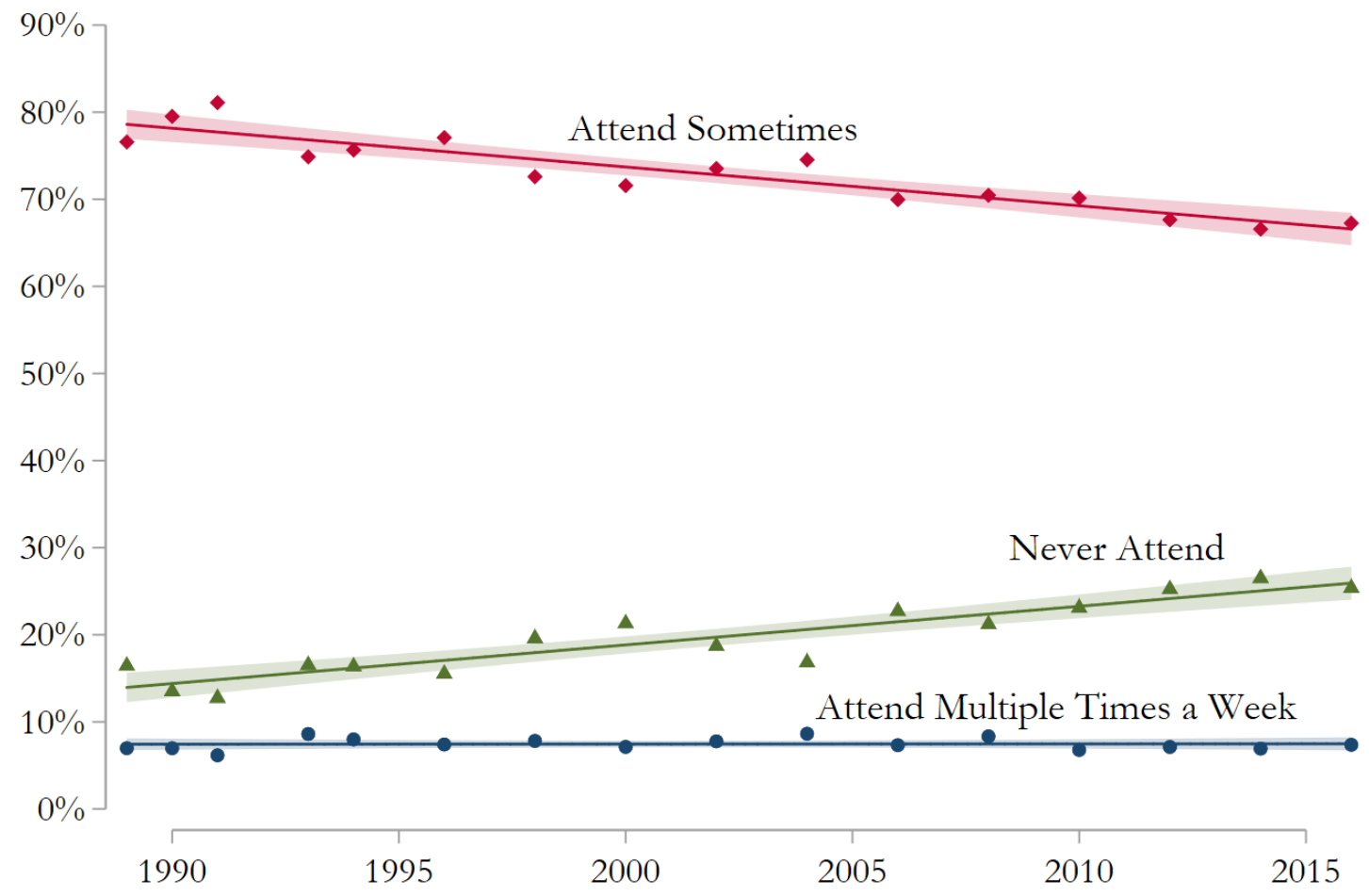

Figure 3: Religious service attendance frequency over time, General Social Survey. Source: General Social Survey, 1989 to 2016. Note: The nine GSS attendance response options are never $=1$, less than once a year $=$ 2 , once a year $=3$, several times a year $=4$, once a month $=5$, several times a month $=6$, nearly weekly $=7$, once a week $=8$, and more than once a week $=9$. "Attend sometimes" includes response options 2 through 8 .

and affiliation, the political gap between intense religionists and secularists has become somewhat larger over time. ${ }^{7}$

Figure 2 shows the pattern for prayer frequency. Unlike the rise of the unaffiliated, there is no rise in those who rarely or never pray. ${ }^{8}$ Not only has the most infrequent prayer category not increased, but the most frequent category has actually increased over time. This slight upward trend in the proportion of the American public who report praying multiple times per day is a function of decline in the more moderate prayer frequency categories, and the most frequent prayer category now makes up a substantially larger proportion of those who pray. In 1989, 31 percent of those who prayed at least once a week did so multiple times a day. In 2016, 40 percent of this group prayed multiple times a day.

Moving from prayer to attendance, Figure 3 shows that, again, the highest category is not declining. Although there were never many people in the category of more-than-weekly attendance, the number in this group is conspicuously consistent. ${ }^{9}$ The rise of those who never attend religious services is solely a function of a substantial decline in the middle categories. 


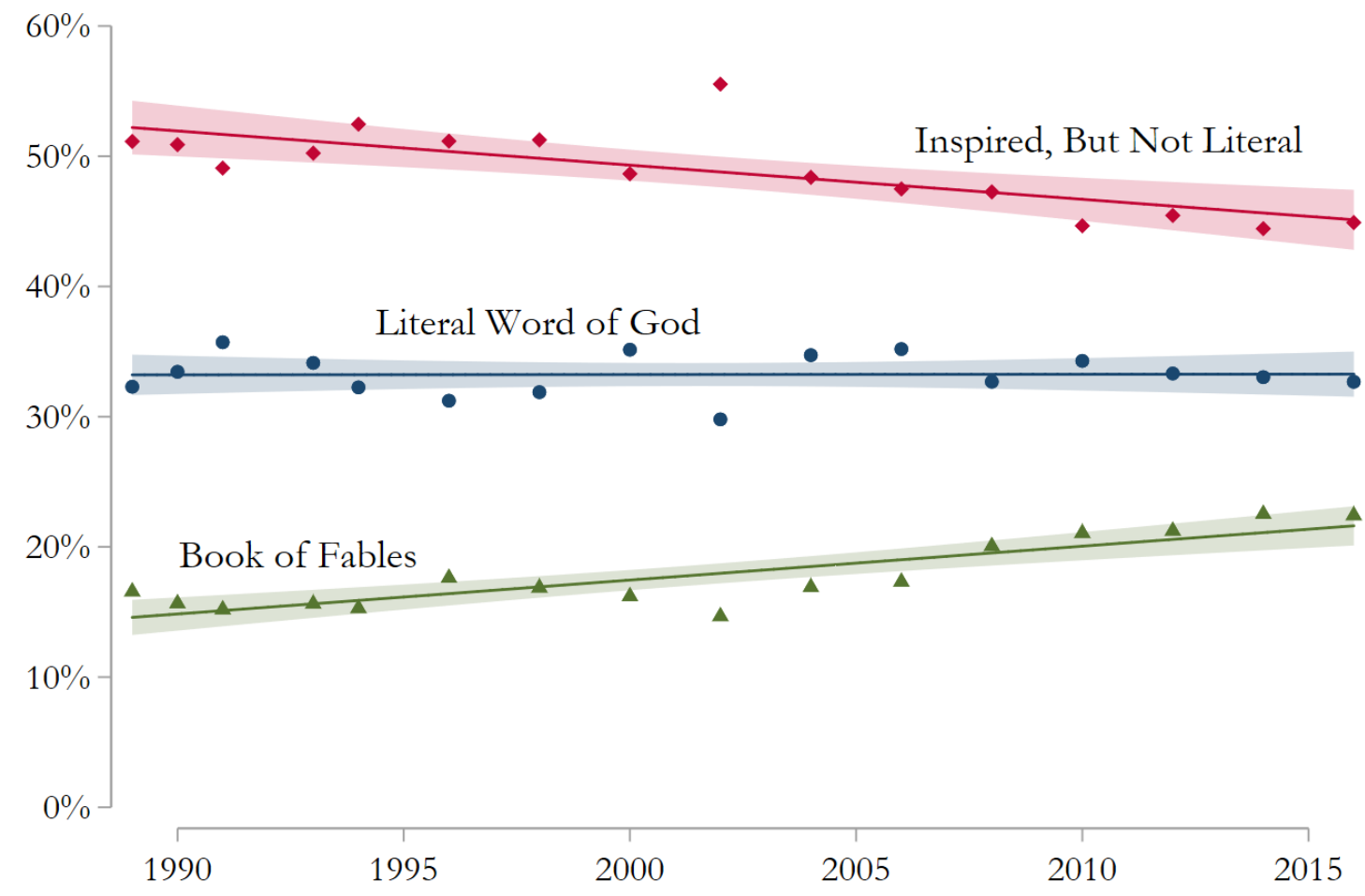

Figure 4: View of Bible over time, General Social Survey. Source: General Social Survey, 1989 to 2016. Note: The GSS question asks which of the three views toward the Bible presented in the figure comes closest to their own. Those who volunteered responses other than the three given were excluded from this analysis.

The previous measures have focused on levels of religiousness, but we now explore types of religious beliefs and identities. Looking at views of the Bible in Figure 4-which is a particularly strong predictor of political views-we see an upward trend in those who see the Bible as a book of fables. But again, the increase in this more secular category is a function of a decline in those who have a more moderate view of the Bible. Biblical literalism persists at about the same level over this time period.

Finally, turning to different types of affiliations, we see in Figure 5 that evangelicals (as measured using the Steensland et al. [2000] schema) are not on the decline in the same way as more moderate religious affiliations. In fact, additional analyses going further back in time demonstrate that evangelicals grew from 1972, when they were 18 percent of the population, to a steady level of about 28 percent from 1989 to 2016. Mainline Protestants, perhaps the most moderate of American religionists, have declined particularly rapidly from 35 percent of the population in 1972 to 12 percent of the population in 2016. Notably, rapid disaffiliation started shortly after evangelicalism rapidly grew and rose to prominence in the public sphere.

We argued that measurement decisions are important in the study of religious change, and for theoretical reasons, we intentionally focused on the most intense 


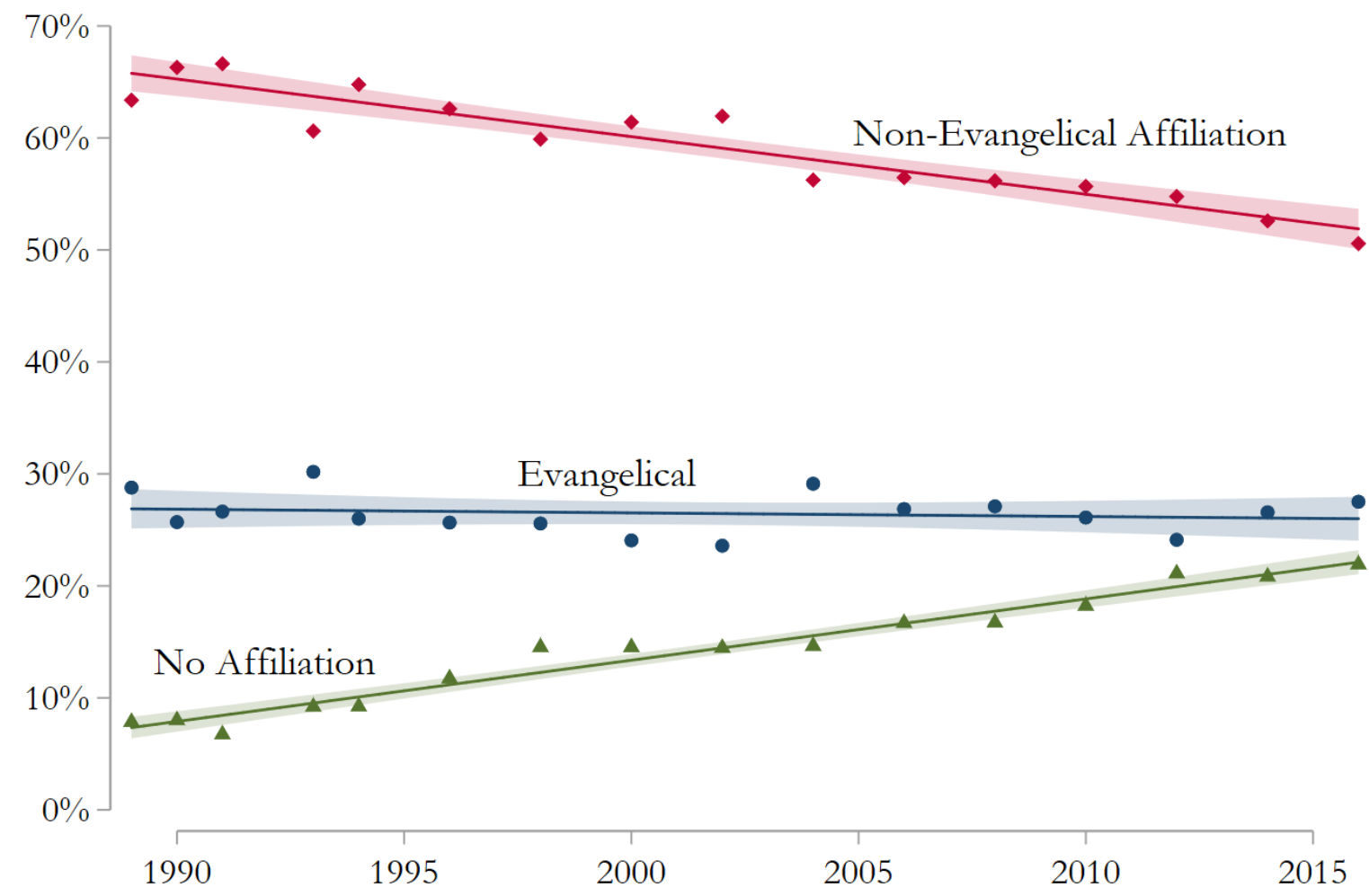

Figure 5: Type of affiliation over time, General Social Survey. Source: General Social Survey, 1989 to 2016. Note: The religious groups were categorized using the Steensland et al. (2000) religious classification schema. The "non-evangelical affiliation" category includes Catholics, mainline Protestants, "Black Protestants," Jews, and "other faiths."

levels of religion. Additional analyses show that, as might be expected on the basis of Hout and Fischer's work, the most intense religion categories are the most persistent. As we illustrate in Figure 6, alternative specifications could be employed to support different narratives. Prayer frequency-which was not included in Voas and Chaves' (2016) study-actually appears to be increasing if coded as more-than-daily versus all others or as daily-or-more versus all others. But if it is dichotomized as weekly-or-more versus all other prayer frequencies, one could argue that prayer frequency is not changing. Trends in attendance frequency can be more readily employed to argue for secularization: only the highest category of more-than-weekly attendance is persistent. Dichotomizing at weekly-or-more attendance yields a slight downward trend, and dichotomizing at monthly-or-more attendance-as Voas and Chaves did—demonstrates a steeper downward trend.

Rather than growing irrelevance of religion in America as suggested by the secularization thesis, rising secularism is solely a function of the decline of moderate religion, as would be expected on the basis of Hout and Fischer's $(2002,2014)$ argument. The highest levels of religious commitment and involvement remain 


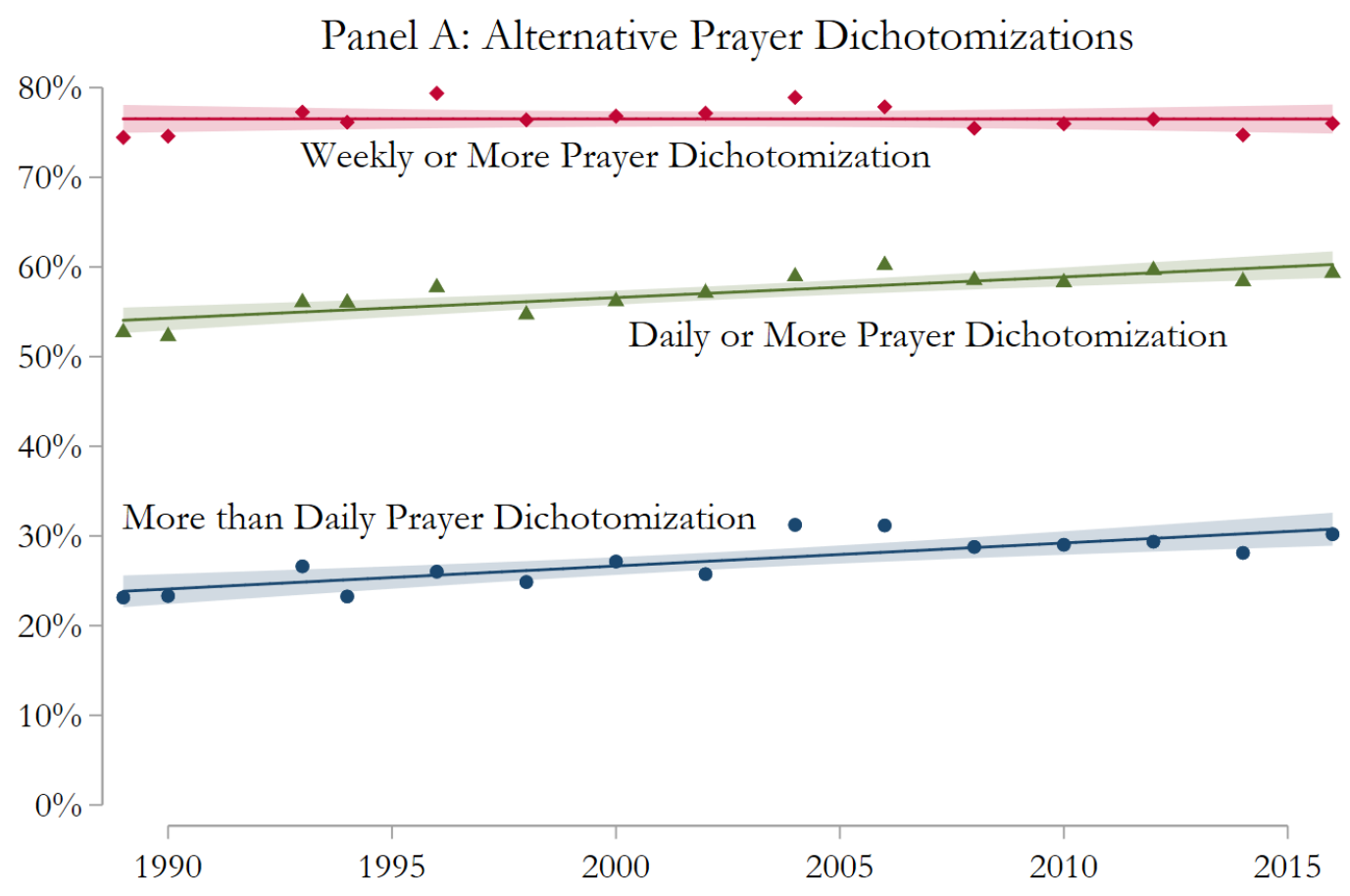

Panel B: Alternative Attendance Dichotomizations

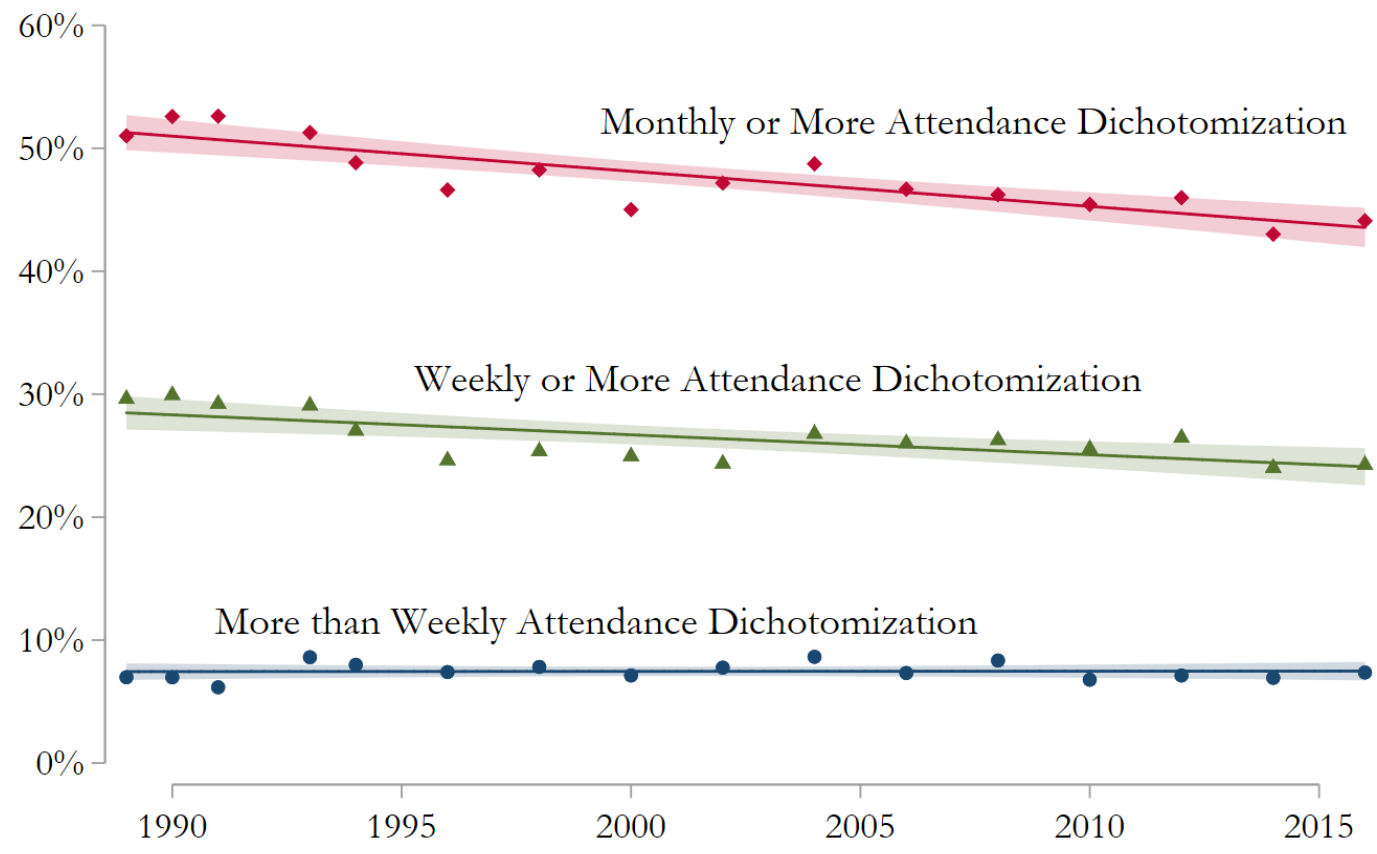

Figure 6: Alternative prayer and attendance frequency dichotomizations. Source: General Social Survey, 1989 to 2016 . 
steady, as do literalism and sectarian identity, demonstrating the persistent intensity of American religion. Because the more moderate groups are shrinking as the more intense categories persist, these intense categories make up a growing proportion of those who are religious.

\section{The Exceptional Intensity of American Religion}

We have shown that the intensity of American religion is persistent across measures, but is this intensity exceptional? More specifically, is there a persistently large, highly religious group resistant to social change across countries, or is this pattern specific to the United States? To compare the United States to similar countries, we use data from the ISSP, a cross-national survey collaboration that includes the U.S. General Social Survey. We use the 2008 religion module (which included prayer frequency and view of the Bible) and the more recent 2014 citizenship module (which included attendance frequency). In order to follow Voas and Chaves' (2016) focus on countries comparable to the United States in terms of culture and economy, we limit our analysis to historically Christian countries with a per capita GDP of at least $\$ 25,000 .^{10}$

Panel A of Figure 7 presents the percentage of respondents who pray multiple times a day in the United States and comparable countries. ${ }^{11}$ The figure includes the percentages for each available country as well as averages both including and excluding the United States. As the figure demonstrates, the United States clearly stands out as exceptional: almost one in three Americans prays multiple times a day, but the average for other countries is only about one in fifteen. Panel B of Figure 7 presents the rate of more-than-weekly attendance. Again, the United States stands out as exceptional, with a rate of more-than-weekly attendance about twice as high as the second-highest country and more than three times as high as the average for other countries. ${ }^{12}$

Clearly, high-frequency religious practice is exceptional in the United States, but maybe American beliefs are not so unique. Panel $C$ of Figure 7 presents the percentage of respondents who believe the Bible is the literal word of God. ${ }^{13}$ This was an optional question and thus was not fielded in as many countries. Again, the United States stands out as exceptional, with about a third of the American public saying the Bible is the literal word of God. In Ireland, the only other country where more than 10 percent of the public are biblical literalists, fewer than one in five people are biblical literalists.

Voas and Chaves (2016) argued that the United States is secularizing similarly to what has occurred in other countries and that it will become less exceptional over time. To consider change across countries, Table 1 presents shifts in intense religion since the first ISSP religion module fielded in 1991. The United States was not so exceptional on the highest level of prayer frequency in 1991, with Ireland actually scoring higher at 22 percent praying more than daily. But since 1991, Americans have become more likely (and people in other countries have become less likely) to pray multiple times a day. Subsequently, in 2008 praying multiple times a day was more than twice as common in the United States than in any of the other countries considered. Although the pattern for attendance is not as dramatic as 


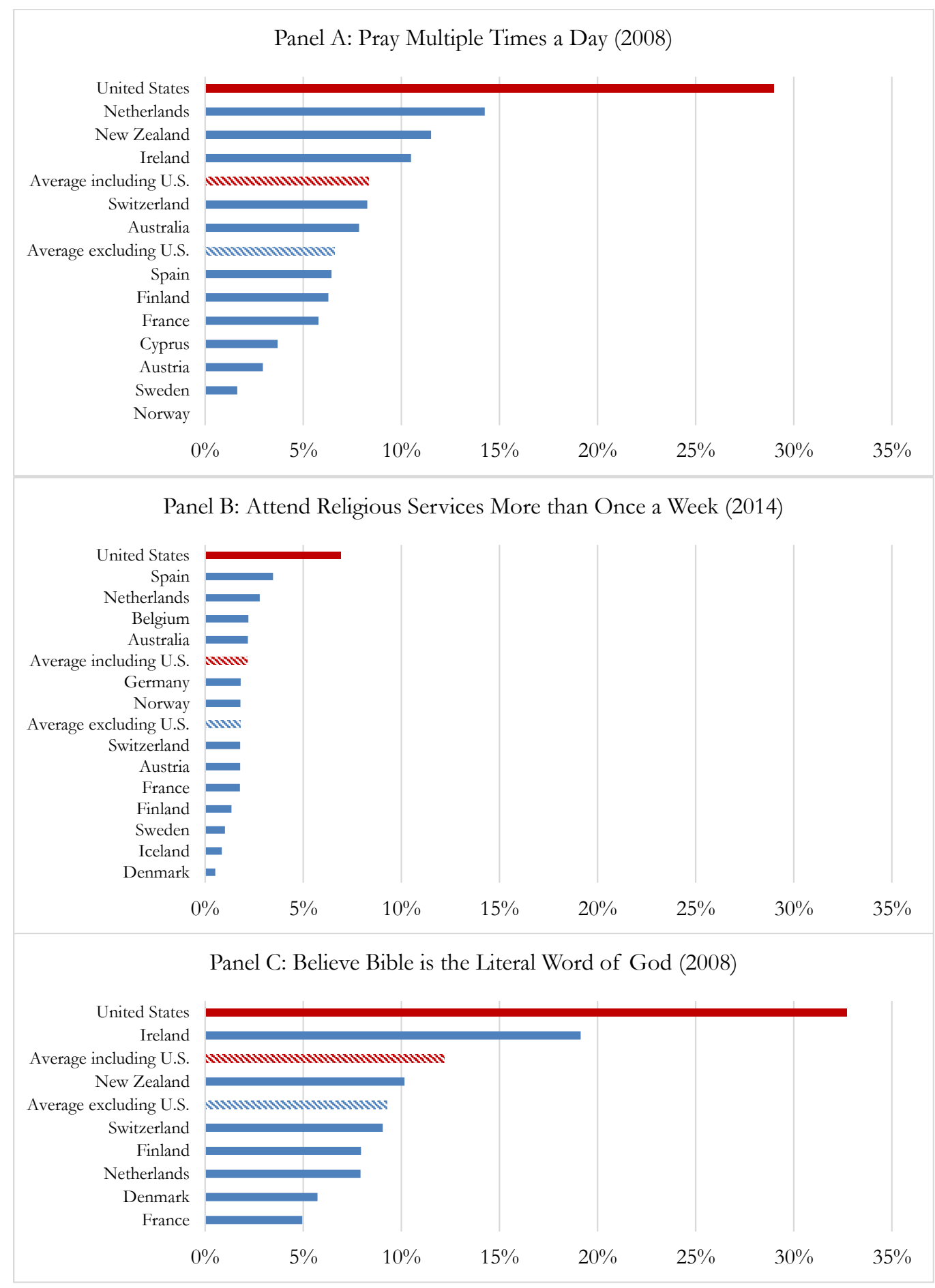

Figure 7: Cross-national intense religion, International Social Survey Programme. Source: International Social Survey Programme, 2008 and 2014. Note: Limited to historically Christian countries where the religion questions included the high intensity option and per capita GDP was at least \$25,000 (World Bank 2010). View of the Bible was an optional question fielded in only some countries. 
Table 1: Cross-national change in intense religion, International Social Survey Programme.

\begin{tabular}{|c|c|c|c|c|}
\hline \multicolumn{5}{|c|}{ Pray Multiple Times a Day } \\
\hline Country & 1991 & 2008 & $\begin{array}{l}\text { Absolute } \\
\text { Difference }\end{array}$ & $\begin{array}{c}\text { Relative } \\
\text { Difference }\end{array}$ \\
\hline United States & $20.5 \%$ & $28.8 \%$ & $+8.3 \%$ & $+40.5 \%$ \\
\hline Ireland & $22.4 \%$ & $10.5 \%$ & $-11.9 \%$ & $-53.1 \%$ \\
\hline Netherlands & $17.2 \%$ & $14.3 \%$ & $-2.9 \%$ & $-16.9 \%$ \\
\hline Australia & $8.9 \%$ & $7.8 \%$ & $-1.1 \%$ & $-12.4 \%$ \\
\hline Norway & $8.7 \%$ & $0 \%$ & $-8.7 \%$ & $-100 \%$ \\
\hline Austria & $4.9 \%$ & $2.9 \%$ & $-2.0 \%$ & $-40.8 \%$ \\
\hline \multicolumn{5}{|c|}{ Attend Religious Services More than Once a Week } \\
\hline Country & 1991 & 2014 & $\begin{array}{l}\text { Absolute } \\
\text { Difference }\end{array}$ & $\begin{array}{c}\text { Relative } \\
\text { Difference }\end{array}$ \\
\hline United States & $5.8 \%$ & $6.9 \%$ & $+1.1 \%$ & $+20.0 \%$ \\
\hline Ireland & $3.5 \%$ & $2.2 \%$ & $-1.3 \%$ & $-37.1 \%$ \\
\hline \multicolumn{5}{|c|}{ Believe Bible Is the Literal Word of God } \\
\hline Country & 1991 & 2008 & $\begin{array}{l}\text { Absolute } \\
\text { Difference }\end{array}$ & $\begin{array}{c}\text { Relative } \\
\text { Difference }\end{array}$ \\
\hline United States & $35.7 \%$ & $32.7 \%$ & $-3.0 \%$ & $-8.4 \%$ \\
\hline Ireland & $25.5 \%$ & $19.1 \%$ & $-6.4 \%$ & $-25.1 \%$ \\
\hline Netherlands & $10.5 \%$ & $7.9 \%$ & $-2.6 \%$ & $-25.8 \%$ \\
\hline New Zealand & $10.1 \%$ & $10.2 \%$ & $+0.1 \%$ & $+1.0 \%$ \\
\hline
\end{tabular}

Source: International Social Survey Programme, 1991, 2008, and 2014.

Note: Limited to historically Christian countries where information was available at both time points and where the religion questions included the high intensity option and per capita GDP was at least \$25,000 (World Bank 2010). 


\section{Conclusion}

Voas and Chaves (2016) showed that average religiousness is declining in the United States, similar to the secularization occurring in other countries, and concluded, therefore, that religion in America is not exceptional, not "declining in a distinctive way," (p. 1524), and "not any sort of outlier" (p. 1550). We have demonstrated, however, that only moderate religion has declined and that the intensity of American religion is persistent and exceptional. The decline of moderate religion is not, therefore, a pervasive secularization consistent with the secularization thesis. Instead, it appears to be a reaction of moderates against religion that has become too intense, too strict, and too politicized in the face of social change (Hout and Fischer 2002, 2014; Iannaccone 1994). Therefore, although religion can gain strength by distinguishing itself from society, it needs to adjust to social change or else risk becoming too distinctive and alienating moderates (Iannaccone 1994; Schnabel 2016).

We have shown that American religion is becoming increasingly exceptional in its intensity. Rather than religion as a whole declining and fading into irrelevanceas we would expect on the basis of the secularization thesis-the political backlash noted by Hout and Fischer $(2002,2014)$ appears to be emptying the more moderate categories of American religion. Yes, we could call this religious change a different type of secularization, but we could also, and perhaps more accurately, call it the polarization of religion in the United States. This pattern of moderates changing and an intransigent category persisting parallels other work on social change in the United States, such as Powell and colleagues' (2010) research on same-sex marriage attitudes: they found that moderates frequently changed their perspective, but those most opposed to same-sex marriage were less likely to change. Likewise, as American religion has become increasingly politicized, moderates have been leaving it. But the most ardently and dogmatically religious persist and now make up a larger share of those who are religious. Even as those who attend religious services sometimes shift toward never attending, there is not a decline in those who attend more than weekly-therefore, clergy are increasingly preaching to the choir.

That American religion is not becoming irrelevant or any less intense has important societal implications. For many social and political issues, there is only a modest distinction between the views of the moderately religious and the nonreligious but a large distinction between intense religionists and everyone else (Schnabel and Sevell 2017). The persistent intensity of American religion in conjunction with the decline of moderate religion may produce a widening cultural gulf between rising secularists and persistently intense religionists. ${ }^{16}$ Subsequently, symbolic boundaries could become more clearly demarcated as there are fewer people to bridge the cultural chasm between the most and least religious Americans. Whereas religion is simply irrelevant to many secularists in comparable societies used to illustrate the secularization thesis, secular and spiritual-but-not-religious Americans often define themselves in opposition to politicized strict religion (Lipka 2016). And although religion is simply becoming less salient in other societies, it remains important in the public sphere and central to cultural divides in the United States. Therefore, rather than following the pattern we would expect on the basis of 
the secularization thesis, American religion remains persistently and exceptionally intense.

\section{Notes}

1 Religiosity, or levels of religiousness, can be measured in a number of different ways, usually with measures of belonging (e.g., strength of affiliation) and behaving (e.g., frequency of religious service attendance), which clearly measure levels of religiousness. Much research also treats belief (e.g., belief in literalism) as an element of religiousness, but beliefs are typically better understood as measures of types rather than levels of religiousness. In this study we focus on what we call intense religion, which we consider to be both a level (the highest levels of commitment and practice) and type (sectarian and literalist) of religion.

2 "Intense religion" refers to a range of related but distinct factors-similar to the "strictness" of American religion highlighted by Kelley (1972) and Iannaccone (1994) — that may be unique to the United States, including strong commitment, very frequent practice, literalism, and sectarian affiliation.

3 We also looked at lowess (locally weighted scatterplot smoothing) fit lines. These lines were very similar to the linear predictions, suggesting that the linear predictions we present for this time period fit the data well.

4 The rapid disaffiliation during this time period, Hout and Fischer $(2002,2014)$ argue, has been driven in large part by political backlash against the Religious Right.

5 In fact, the percentage of people with a strong affiliation has been consistent all the way back to 1974, when this variable was first fielded.

6 We also considered patterns among young people on this and other measures and found similar patterns of persistent intensity. Looking just at people aged 25 and under-a relatively small proportion of the sample for which we would expect some year-to-year fluctuation-26 percent were strongly affiliated in 1974, 22 percent in 1988, and 25 percent in 2016. Whereas strong affiliation remained consistent, no affiliation among those 25 and under almost tripled from 13 percent in 1974 to 35 percent in 2016. The percentages for strong affiliation are lower overall for this group than those for all Americans-which suggests that people may age into strong affiliation, as we are effectively controlling for cohort by looking at the same age group over time-but are similarly consistent.

7 Ancillary regression analyses predicted conservative political views (extremely liberal $=1$ to extremely conservative $=7$ ), with strength of affiliation interacted with year. We found a modest but significant interaction effect between strong affiliation vs. no affiliation and survey year. This finding indicates a broadening of the political gap between conservative strong affiliates and the liberal unaffiliated.

8 The General Social Survey now includes a "never pray" option, but this was only included after 2004, so we focus on those who pray multiple times a day, those who pray less than once a week (which includes those who never pray), and those in between.

9 In fact, the percentage of people who attend more than weekly has remained steady all the way back to 1972 .

10 Some of the most secular countries in the ISSP could not be included in these analyses because they did not include more-than-daily prayer or more-than-weekly attendance as response options. 
11 There were no people who indicated praying multiple times a day in Norway. We checked the original ISSP questionnaire for Norway and the prayer frequency question did include a multiple-times-a-day response option, which it appears no Norwegian respondents selected.

12 Additional analyses considered the United States in comparison to other countries just among young adults to ensure U.S. distinctiveness on this and other measures is not just a function of intense religion among older Americans. We again found U.S. religion distinctively intense among young people.

13 American levels of literalism would be even more exceptional were it not for the view of the Bible question including a "does not apply" option in countries besides the United States. We excluded this "does not apply" category from the calculations for percentage literalist because it was not available in the United States. When including this category in the calculations for percentage literalist in other countries, the percentage who are literalists in countries besides the United States is notably lower, and the United States thus appears even more exceptional.

14 The ISSP changes which countries it includes, and a more-than-weekly attendance option has not been fielded in many countries until more recently, so only the United States and Australia fielded equivalent attendance questions in both 1991 and 2014.

15 Looking back at Figure 4 shows that the "decline" in American literalism from 36 percent to 33 percent was year-to-year fluctuation.

16 Our findings about movement out of the moderate category suggest that social change more generally may be most possible among moderates, whereas the extremes may be more unchangeable. Those seeking to effectively foster social change may want to target moderates rather than trying to change the minds of more entrenched people.

\section{References}

Bruce, Steve. 2011. Secularization: In Defence of an Unfashionable Theory. Oxford: Oxford University Press. https://doi.org/10.1093/acprof : osobl/9780199654123.001.0001

Djupe, Paul A., Jacob R. Neiheisel, and Anand E. Sokhey. 2017. "Reconsidering the Role of Politics in Leaving Religion: The Importance of Affiliation." American Journal of Political Science. Published online ahead of print. https://doi .org/10.1111/ajps.12308

Hout, Michael, and Claude Fischer. 2002. "Why More Americans Have No Religious Preference: Politics and Generations." American Sociological Review 67(2):165-90. https : //doi.org/10.2307/3088891

Hout, Michael, and Claude Fischer. 2003. “O Be Some Other Name." American Sociological Review 68(2):316-18. https://doi .org/10.2307/1519772

Hout, Michael and Claude Fischer. 2014. “Explaining Why More Americans Have No Religious Preference: Political Backlash and Generational Succession, 1987-2012." Sociological Science 1:423-47. https://doi.org/10.15195/v1.a24

Iannaccone, Laurence R. 1994. "Why Strict Churches Are Strong." American Journal of Sociology 99(5):1180-211. https://doi .org/10.1086/230409

Kelley, Dean. 1972. Why Conservative Churches Are Growing. Macon, GA: Mercer University Press.

Lipka, Michael. 2016. “Why America's 'Nones' Left Religion Behind." Pew Research Center. Retrieved October 5, 2017. http://www . pewresearch.org/fact-tank/2016/08/ 24/why-americas-nones-left-religion-behind/. 
Marwell, Gerald, and N. J. Demerath III. 2003. "'Secularization' by Any Other Name." American Sociological Review 68(2):314-16. https://doi .org/10.2307/1519771

Powell, Brian, Catherine Bolzendahl, Claudia Geist, and Lala Carr Steelman. 2010. Counted Out: Same-Sex Relations and Americans' Definitions of Family. New York: Russell Sage.

Schnabel, Landon. 2016. "Gender and Homosexuality Attitudes across Religious Groups from the 1970s to 2014: Similarity, Distinction, and Adaptation." Social Science Research 55(1):31-47. https://doi.org/10.1016/j.ssresearch.2015.09.012

Schnabel, Landon, and Eric Sevell. 2017. "Should Mary and Jane Be Legal? Americans' Attitudes toward Marijuana and Same-Sex Marriage Legalization, 1988-2014." Public Opinion Quarterly 81(1):157-72. https : //doi . org/10 .1093/poq/nf w050

Steensland, Brian, Jerry Z. Park, Mark D. Regnerus, Lynn D. Robinson, W. Bradford Wilcox, and Robert D. Woodberry. 2000. "The Measure of American Religion: Toward Improving the State of the Art." Social Forces 79(1):291-318. https://doi .org/10.1093/sf/79.1. 291

Voas, David, and Mark Chaves. 2016. "Is the United States a Counterexample to the Secularization Thesis?" American Journal of Sociology 121(5):1517-56. https : //doi .org/ $10.1086 / 684202$

World Bank. 2010. "GDP per capita (constant 2010 US\$)." Retrieved March 20, 2017. https : // data . worldbank. org/indicator/NY.GDP.PCAP.KD?end=2010\&year_high_desc=true

Acknowledgements: The authors are grateful to Brian Powell and Clem Brooks for exceptional feedback. Direct correspondence to Landon Schnabel, Department of Sociology, Indiana University Bloomington, 744 Ballantine Hall, 1020 E. Kirkwood Ave., Bloomington, IN 47405.

Landon Schnabel: Department of Sociology, Indiana University Bloomington. E-mail: lpschnab@indiana.edu.

Sean Bock: Department of Sociology, Harvard University. E-mail: seanbock@g.harvard.edu. 